\title{
The effects of forest disturbances on flying insect assemblages in Trawas, East Java
}

\author{
Amin Setyo LeKsono ${ }^{1,2) *}$, Nobukazu NaKAgoshi ${ }^{1)}$ and Yuji IsAgI ${ }^{1)}$ \\ ${ }^{1)}$ Graduate School for International Development and Cooperation, Hiroshima University, 1-5-1 Kagamiyama, Higashi-Hiroshima, 739-8529 \\ Japan \\ ${ }^{2)}$ Jurusan Biologi, FMIPA UNIBRAW, Malang, Indonesia \\ *Corresponding author. Tel/Fax: 082-424-6957, E-mail: leksono72@yahoo.com
}

\begin{abstract}
To evaluate the effects of forest disturbances on flying insects, samples were taken at three selected disturbed sites in a mountainous area in Trawas, East Java. Changes in the abundance, family richness and composition of flying insects were monitored during the 2003 wet season and 2004 dry season using window traps. A total of 4947 individuals of insects, representing 82 families, were collected. The overall abundance and family richness of flying insects declined with increasing site disturbance. Community composition was also remarkably different among the sites. Herbivorous insects, such as Chrysomelidae and Orthoptera, and scavenging beetles, such as Scolytidae and Nitidulidae, were the most sensitive to disturbance. In contrast, some agricultural insects were found in highlydisturbed site. These results indicate that forest disturbances change flying insect composition.
\end{abstract}

Key words: Anthropogenic disturbance, East Java, flying insect, tropical region, window trap

\section{INTRODUCTION}

Concerns about the effects of tropical forest disturbance, e.g. clearance, on the biodiversity of arthropods have been reported in several studies (Hamer et al., 1997; Chey et al., 1998; Holloway, 1998; Lawton et al., 1998; Schowalter \& Ganio, 1999). A more recent study evaluates the effects of disturbance, particularly by human activities, on arthropod assemblages in a lowland forest (Floren \& Linsenmair, 2001, 2003). In most of those studies, arthropod assemblages were sampled using an application of insecticide by fogging. Canopy fogging, despite its effectiveness in collecting flying insects and frequent application since the early 1970s (e.g., Roberts, 1973), has some intrinsic disadvantages, including the difficulty to get a high number of spatial replicates, laboriousness and costly equipment (Basset $e t$ al., 2003). Since sampling cost and processing time is often a major consideration in ecological investigations in developing countries, it is unavoidable to use inexpensive traps such as window traps.

Window traps have been used to study the distribution and composition of flying insects in temperate forests (Didham, 1997; Su \& Woods, 2001). However, these studies were typically carried out at locations without disturbance. Studies on flying insects and anthropogenic disturbance events remain scarce (e.g., Lawton et al., 1998).

Habitat destruction and fragmentation, species introduction and afforestation are major problems in tropical regions. These problems seem to seriously impact insect communities and diversity (Chey et al., 1998; Floren \& Linsenmair, 2001, 2003). On Java Island there is rapid destruction, even in mountainous forests, for which information and data on insect abundance and the influence of forest disturbance are virtually not available. The objective of this study is to evaluate the effects of disturbances on flying insects by comparing their abundance, richness and composition along a gradient of less-disturbed to highly-disturbed in a mountainous area of tropical forest.

\section{MATERIALS AND METHODS}

Study site

The study was carried out in Trawas, a hilly upland at the foot of Penanggungan Mt. of East Java, Indonesia $\left(7^{\circ} 43^{\prime} \mathrm{S}, 112^{\circ}\right.$ $37^{\prime} \mathrm{E}, 850 \mathrm{~m}$ in altitude) (Fig. 1). The area was originally characterized by a mixed secondary forest dominated by Celtis australis and Alstonia scolaris. Over the past two decades, the landscape has been transformed to agricultural ecosystems mostly by the local people. In the early 1990s, a local non-governmental organization, PPLH/Environmental Education Center, was established, and it later managed some parts of this area. In this study site, insect sampling was performed 


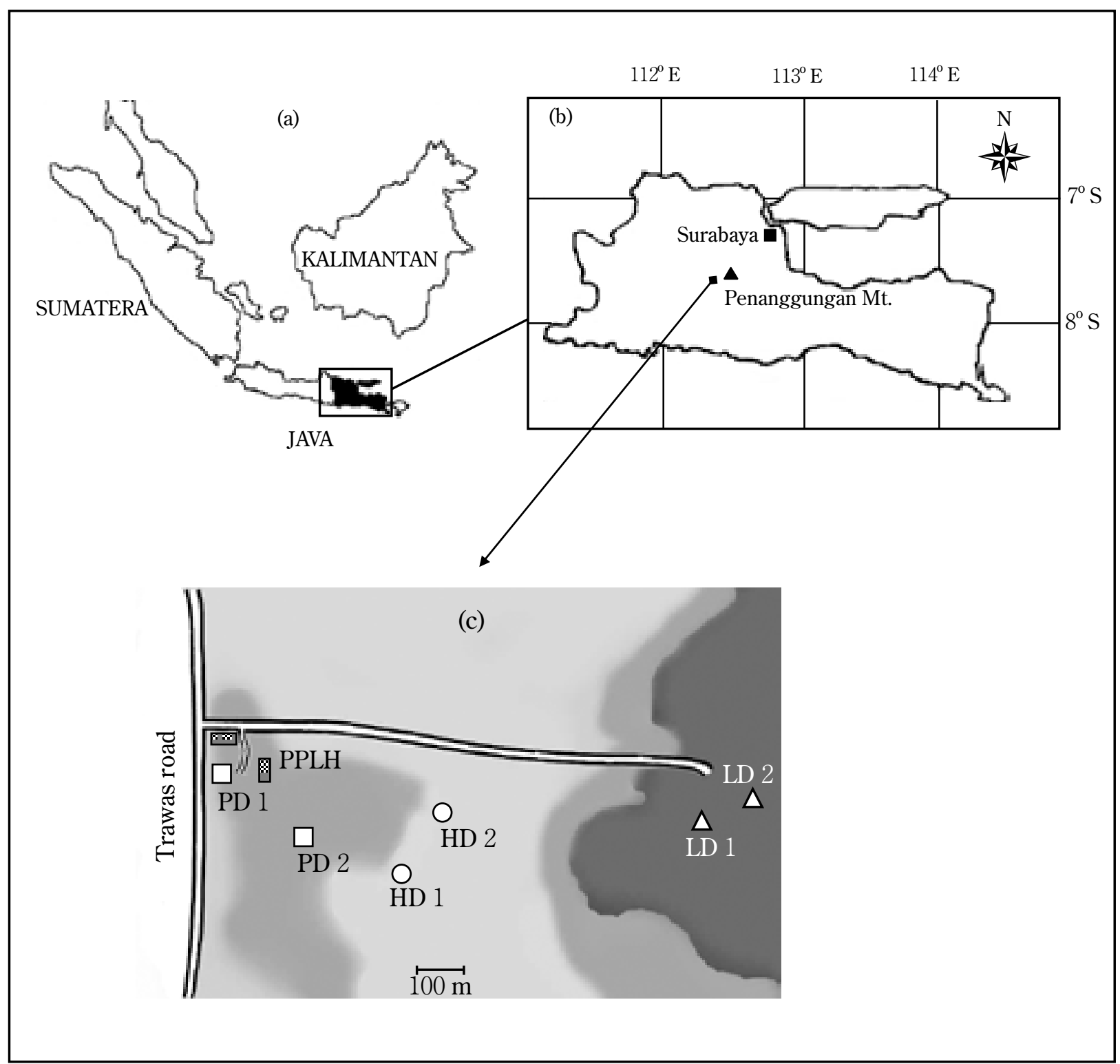

Fig. 1. Location of study sites: (a) Geographical map of Indonesia, (b) East Java Region, (c) Location of a six stands representing three disturbance levels. $\square$, Less-disturbed site (LD); $\square$, partly-disturbed site (PD); $\square$, highly-disturbed site.

at three sites along a gradient of disturbance from a less-disturbed (LD) site in an upper hilly area, through a partlydisturbed (PD) site managed by PPLH, to a highly-disturbed site (HD). These three sites have different vegetation types relating to the level of disturbance (Table 1).

\section{Insect sampling and processing}

Canopy insects were collected during the wet season in November/December 2003 and dry season in July/August 2004 using window traps. At each site, two standing trees were randomly selected to suspend the traps. Traps were suspended at 0.5 to $1.5 \mathrm{~m}$ and 15 to $25 \mathrm{~m}$ above the ground level in the understorey layer and canopy layer, respectively. Each trap was set for four periods of seven days. The traps were constructed by intersecting two square planes of clear plastic, each $45 \mathrm{~cm}$ by $45 \mathrm{~cm}$, in a "+" shape when viewed from above. The plastic planes formed a total of eight panel surfaces to intercept flying insects. A yellow circular pan of $46 \mathrm{~cm}$ in diameter and $16 \mathrm{~cm}$ in height was attached underneath the panels to catch the trapped insects. The pan was filled with two liters of water mixed with a few drops of detergent and sorbic acid to kill and preserve the insects caught in the trap. 
Table 1. Characteristics of different sites along disturbance gradient in Trawas secondary forest, East Java

\begin{tabular}{|c|c|c|c|}
\hline Variable & $\begin{array}{l}\text { Less-disturbed site } \\
\text { (LD) }\end{array}$ & $\begin{array}{l}\text { Partly-disturbed site } \\
\text { (PD) }\end{array}$ & $\begin{array}{l}\text { Highly-disturbed site } \\
\text { (HD) }\end{array}$ \\
\hline Shrubs/grass plants & $\begin{array}{l}\text { Mikania cordata, } \\
\text { Synedrella nodiflora, } \\
\text { Hoplismenus } \\
\text { burmanii, Alpinia } \\
\text { zerumbet }\end{array}$ & $\begin{array}{l}\text { Mikania cordata, } \\
\text { Ageratum conyzoides, } \\
\text { Axonopus compressus, } \\
\text { Hyptis capitata, } \\
\text { Stachytarpheta } \\
\text { jamaicensis }\end{array}$ & $\begin{array}{l}\text { Hoplismenus burmanii, } \\
\text { Salvia riparia, Morinda } \\
\text { citrifolia, Musa } \\
\text { paradisiaca, Capsicum } \\
\text { sp. Solanum torvum, } \\
\text { Zea mays }\end{array}$ \\
\hline Canopy trees & $\begin{array}{l}\text { Celtis australis, } \\
\text { Alstonia scolaris, } \\
\text { Garcinia dulcis, } \\
\text { Ficus benjamina }\end{array}$ & $\begin{array}{l}\text { Sweitenia mahagoni, } \\
\text { Alstonia scolaris, Ceiba } \\
\text { petandra, Mangifera } \\
\text { indica, Eugenia uniflora }\end{array}$ & $\begin{array}{l}\text { Celtis australis, Ficus } \\
\text { benjamina, Eugenia } \\
\text { uniflora }\end{array}$ \\
\hline \multicolumn{4}{|l|}{ Vegetation cover (\%) } \\
\hline Understorey layer* & $73.75 \pm 5.24$ & $37.50 \pm 10.04$ & $70.00 \pm 6.55$ \\
\hline Canopy layer & $77.50 \pm 8.29$ & $81.25 \pm 5.91$ & $56.25 \pm 9.87$ \\
\hline \multicolumn{4}{|l|}{ Vegetation height (m) } \\
\hline Understorey layer & $0.63 \pm 0.12$ & $0.14 \pm 0.04$ & $0.57 \pm 0.34$ \\
\hline Canopy layer & $16.93 \pm 4.14$ & $12.68 \pm 1.78$ & $20.60 \pm 6.4$ \\
\hline Distance between trees ${ }^{* *}(\mathrm{~m})$ & $6.68 \pm 0.76$ & $4.06 \pm 0.73$ & $10.56 \pm 2.21$ \\
\hline Type of disturbance & $\begin{array}{l}\text { Less than } 20 \% \\
\text { manual clearance, } \\
\text { hunting and branch } \\
\text { pruning }\end{array}$ & $\begin{array}{l}\text { Less than } 50 \% \text { manual } \\
\text { clearance, plus partial } \\
\text { conversion with exotic } \\
\text { tree species }\end{array}$ & $\begin{array}{l}\text { More than } 70 \% \text { manual } \\
\text { clearance, plus } \\
\text { agricultural plantation }\end{array}$ \\
\hline
\end{tabular}

Significant disturbance effect, Friedman's test, ${ }^{*} P<0.05,{ }^{* *} P<0.01$

The focus of this study was on flying insects, not on immature, flightless or typically soil-inhabiting arthropods. The insects collected from each sampling unit were sorted into families Coleoptera, Diptera, Lepidoptera, Hymenoptera, Homoptera, Isoptera and Hemiptera based on Borror et al. (1989). Common agricultural insects were identified as much as possible to genera or species based on Kalshoven (1981). Other flying insects such as Tysanoptera and Psocoptera were collected by window traps, but excluded from the results.

\section{Vegetation characteristics}

Within each site, characterization of vegetation was carried out at four plots (two plots in each stand), from August 12 to 14,2004 . In each plot, the percentage of understorey cover and vegetation height were estimated visually in $5 \times 5$ $\mathrm{m}^{2}$ quadrates. The heights of herbaceous plants and shrubs were measured using a measuring tape, while tree heights were estimated with a hagameter. Tree composition was surveyed by the quadrant method, starting at the center of the plot. The degree of disturbance of each site was visually estimated in surveys from 2001 to 2004. Vegetation data were compared adopting nonparametric statistical analysis (Friedman's test).

\section{The effect of disturbance on abundance and family richness}

The abundance (number of individuals) and family richness (number of families) for each order, and the abundance of common families were analyzed separately. We compared abundance and family richness between sites, seasons and layers by adopting a general linear model (GLM) repeated-measures analysis of variance (ANOVA), with sites (lessdisturbed, partly-disturbed and highly-disturbed), seasons (wet and dry) and layers (understorey and canopy) as between-subject factors and sampling dates as a within-subject factor. The number of individuals was transformed to the $\log _{10}(\mathrm{x}+1)$ form to improve data normality and variance constancy. The tests were performed using SPSS ${ }^{\circledR}$ version 11.5 (SPSS Inc. Chicago, IL, USA), in agreement with Sokal \& Rohlf (1995), and the $F$-statistic test was considered significant 
when $P<0.05$.

\section{Testing differences in community composition}

Insect community composition was compared among all sampling points in which the data for understorey and canopy samples were calculated independently at the family level. To examine simultaneous pair wise similarity of insect communities among all treatments, the Bray-Curtis percent similarity was calculated for all captured, followed by un-weighted pair-group method using arithmetic average (UPGMA) cluster analysis.

A canonical correspondence analysis (CCA) was applied to analyze the relationship between the abundance of family and environmental factors (site, season, and layer) using the CANOCO version 4.5 (Biometris, Wageningen University and Research Centre, Wageningen, The Netherlands). All factors were coded as categorical variables. Rare families (less than 40 individuals) were excluded from analysis. The families and environmental factors were clustered by $k$-means clustering with the use of SPSS ${ }^{\circledast}$ (see Natuhara et al., 1999).

\section{RESULTS}

A total of 4947 individuals of flying insects, representing 82 families, were collected from the entire study. The proportion of flying insect individuals was highest in the less-disturbed site (40\%) and lowest in the highly-disturbed site (28\%). The mean of family richness was also highest in the former (31.59 \pm 0.82 families) and lowest in the latter (18.44 \pm 0.58 families). Overall, Coleoptera (31\%) and Diptera (29\%) were most abundant in the samples, followed by Hymenoptera (20\%) and Lepidoptera (8\%).

Table 2. Summary of $F$-values, followed by significance of GLM repeated-measure ANOVA for flying insect orders

\begin{tabular}{|c|c|c|c|c|c|c|c|}
\hline \multirow[t]{2}{*}{ Order } & \multicolumn{3}{|c|}{ Factor } & \multicolumn{4}{|c|}{ Interaction between factors } \\
\hline & Site (a) & Season (b) & Layer (c) & $\mathrm{a} \times \mathrm{b}$ & $a \times c$ & $\mathrm{~b} \times \mathrm{c}$ & $\mathrm{a} \times \mathrm{b} \times \mathrm{c}$ \\
\hline \multicolumn{8}{|l|}{ Coleoptera } \\
\hline $\mathrm{A}$ & $66.06^{* * *}$ & $33.52^{* * *}$ & 0.32 & $7.99^{* *}$ & 0.51 & 0.21 & 0.93 \\
\hline $\mathrm{R}$ & $11.49^{* *}$ & 0.74 & 0.39 & $88.40^{* * *}$ & 0.56 & 0.77 & 0.09 \\
\hline \multicolumn{8}{|l|}{ Diptera } \\
\hline A & 1.45 & 1.77 & 0.00 & 0.01 & 0.08 & 0.03 & 0.05 \\
\hline $\mathrm{R}$ & 1.73 & 0.87 & 0.02 & 0.01 & 0.01 & 0.13 & 0.02 \\
\hline \multicolumn{8}{|c|}{ Hymenoptera } \\
\hline $\mathrm{A}$ & 0.68 & $13.49 * *$ & 0.02 & 0.09 & 0.20 & 0.02 & 0.06 \\
\hline $\mathrm{R}$ & $4.85^{*}$ & 2.96 & 0.61 & 0.04 & 0.25 & 0.00 & 0.01 \\
\hline \multicolumn{8}{|c|}{ Lepidoptera } \\
\hline A & 1.15 & 0.02 & 0.10 & 0.64 & 0.06 & 0.05 & 0.05 \\
\hline $\mathrm{R}$ & 2.33 & 0.04 & 0.04 & 0.06 & 0.00 & 0.01 & 0.09 \\
\hline \multicolumn{8}{|l|}{ Homoptera } \\
\hline $\mathrm{A}$ & 2.38 & 1.90 & 0.36 & 0.12 & 0.36 & 0.11 & 0.08 \\
\hline $\mathrm{R}$ & 2.48 & 1.01 & 0.05 & 0.24 & 0.27 & 0.10 & 0.00 \\
\hline \multicolumn{8}{|l|}{ Hemiptera } \\
\hline A & $16.40^{* * *}$ & 0.00 & 1.92 & 0.22 & 1.92 & 0.22 & 0.22 \\
\hline $\mathrm{R}$ & 20.00 & 0.00 & 3.20 & 0.00 & 3.20 & 0.00 & 0.00 \\
\hline \multicolumn{8}{|l|}{ Isoptera } \\
\hline $\mathrm{A}$ & 1.00 & $9.15^{*}$ & 0.16 & 0.13 & 0.26 & 1.04 & 0.02 \\
\hline \multicolumn{8}{|l|}{ Orthoptera } \\
\hline $\mathrm{A}$ & $35.13^{* * *}$ & 2.01 & 3.46 & 0.42 & 1.32 & 0.50 & 0.08 \\
\hline $\mathrm{R}$ & 44.39 & 2.08 & 2.57 & 0.53 & 0.87 & 0.85 & 0.02 \\
\hline \multicolumn{8}{|l|}{ Total } \\
\hline A & $4.93^{*}$ & $12.33^{* *}$ & 0.09 & 0.62 & 0.17 & 0.07 & 0.11 \\
\hline $\mathrm{R}$ & $11.51^{* *}$ & 3.51 & 0.15 & 0.09 & 0.01 & 0.03 & 0.08 \\
\hline
\end{tabular}

Note: $\mathrm{A}=$ abundance, $\mathrm{R}=$ family richness, ${ }^{*} P<0.05,{ }^{* *} P<0.01,{ }^{* * *} P<0.001$ 
Similarity coefficient (\%)

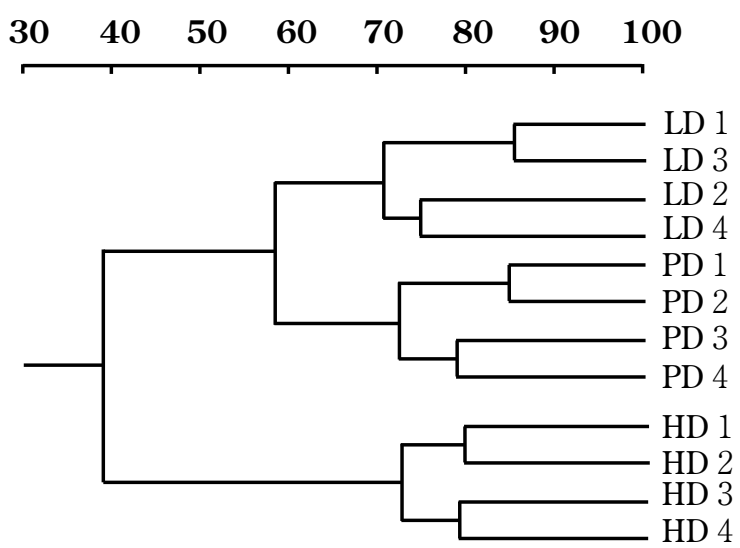

Fig. 2. Dendogram showing the hierarchical cluster for the similarity of insect assemblages based on Bray-Curtis similarity indices (\%). LD (less-disturbed), PD (partly-disturbed), HD (highly-disturbed), 1 (wet season, canopy layer), 2 (wet season, understorey layer), 3 (dry season, canopy layer), 4 (dry season, understorey layer).

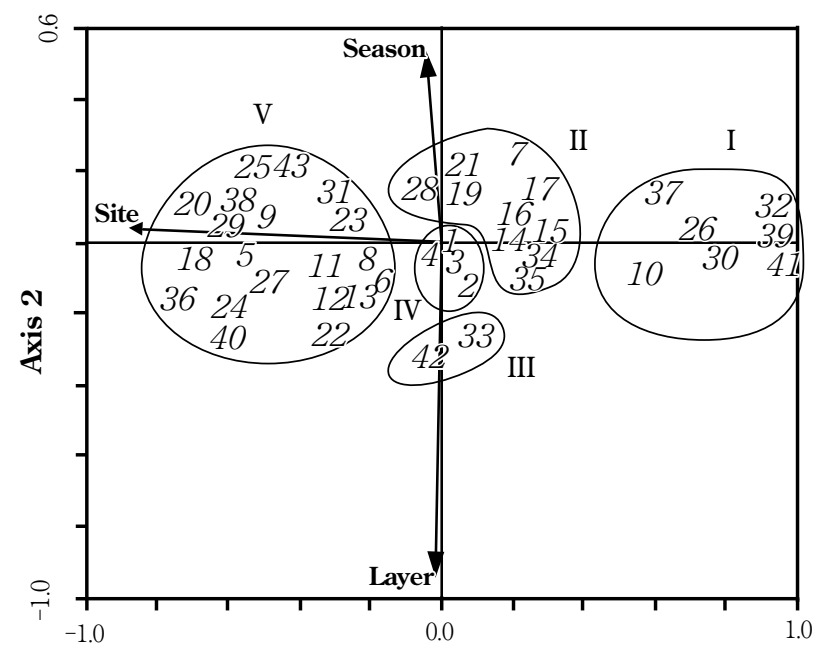

Axis 1

Fig. 3. Ordination of family compositions responding to environment factors: arrows represent degree of environmental variable. The numbers of families enclosed were grouped by $\boldsymbol{k}$-means clustering. Numbers in family score are as follows: 1. Formicidae, 2. Mycetophilidae, 3. Curculionidae 4. Ceratopogonidae, 5. Phoridae, 6. Scolytidae, 7. Membracidae, 8. Tiphiidae, 9. Unknown orthoptera, 10. Termitidae, 11. Nitidulidae, 12. Muscidae, 13. Chrysomelidae, 14. Noctuidae, 15. Ichneumonidae, 16. Throscidae, 17. Lycaenidae, 18. Asilidae, 19. Apidae, 20. Dolichopodidae, 21. Carabidae, 22. Grillidae, 23. Leiodidae, 24. Scarabaeidae, 25. Pieridae, 26. Coccinellidae, 27. Staphylinidae, 28. Masaridae, 29. Ephydridae, 30. Cecidomyiidae, 31. Cicadellidae, 32. Hesperidae, 33. Braconidae, 34. Chironomidae, 35. Gasteruptiidae, 36. Scaphidiidae, 37. Cerambycidae, 38. Mordellidae, 39. Tabanidae, 40. Monotomidae, 41. Tephritidae, 42. Melandryidae, 43. Papilionidae 


\section{Influence of disturbance and season}

The GLM repeated-measures ANOVA produced the most comprehensive evidence of variation in the abundance and family richness of flying insects along the disturbance gradient (Table 2). The effect of disturbance was significant in the overall abundance $(F=4.93$, d.f. $=2, P<0.05)$ and family richness $(F=11.51$, d.f. $=2, P<0.01)$. Both were lowest in the highly-disturbed site. Disturbance and season also had significant effects on the abundance and family richness in several groups (Table 2). There was a significant disturbance effect on the abundance and family richness in Coleoptera ( $F=66.06$, d.f. $=2, P<0.001$ for abundance; $F=11.49$, d.f. $=2, P<0.01$ for family richness). In this group, the effect was significant for phytophagous beetles belong to Chrysomelidae, $(F=6.53$, d.f. $=2, P<0.05)$ and scavengers belong to Scolytidae, $(F=6.58$, d.f. $=2, P<0.05)$ and Nitidulidae $(F=33.71$, d.f. $=2, P<0.001)$. The abundance of these beetles was lowest in highly-disturbed site than in less-disturbed and partly-disturbed site (Table 3). In contrast, the abundance of the agricultural beetles, Adalia spp. (Coccinellidae) was highest in the highly-disturbed site than other sites (Table 2) and it was statistically significant $(F=24.42$, d.f. $=2, P<0.001)$. Disturbances also significantly effected family richness in Hymenoptera $(F=4.85$, d.f $=2, P<0.05)$, but the abundance was not significantly different among sites. In contrast, the abundance of Orthoptera and Hemiptera were influenced by disturbance $(F=35.13$, d.f $=2, P<0.001$ for Orthoptera; $\mathrm{F}=$ 16.40, d.f $=2, P<0.001$ for Hemiptera), but family richness was not significantly different among sites.

Season had a significant effect on some groups, such as Coleoptera $(F=32.52$, d.f $=1, P<0.001)$ and Hymenoptera $(F=13.49$, d.f $=1, P<0.01)$. In general, the abundance of Coleoptera, Hymenoptera and Isoptera decreased in the dry season (Table 3). In combination with the effect of site location, Coleoptera showed a high variation in abundance along a gradient of disturbances related with season. For all groups, the effect of layer was not significant (Table 2).

\section{Community composition}

Results of the UPGMA cluster analysis showed that flying insect assemblages were clustered according to their site within the disturbance gradient (Fig. 2). Family similarity was greater between the less-disturbed and partly-disturbed sites than between both sites and the highly-disturbed site. Branching between the less-disturbed site and partlydisturbed site occurred at $58.5 \%$, while that between two sites and the highly-disturbed site occurred at $39 \%$ (Fig. 2).

\section{Family ordination}

Canonical Correspondence Analysis revealed that an environmental variable was significantly explained the variance in family abundance pattern. The sum of the first two canonical eigenvalues was 0.23 . The first axis, with a correlation of 0.91 between family and environmental factor, explained $94.7 \%$ of the family-environment relations and $55 \%$ of family variation. The second axis showed a 0.90 family-environment correlation, and cumulative with the first axis explained $97.5 \%$ of the family-environment relations and $56.6 \%$ of family variation. The site significantly explained variation in family composition ( $\lambda=0.22, F=12.22, P<0.01$ ), while layer and season were not significant. Summary of the Monte Carlo test showed that the first canonical axis was significant $(F=9.78, P=0.002)$.

The score of the CCA are plotted for families in Figure 3. We classified the families into five groups. Group I was highly tolerant to disturbance and includes Termitidae, Coccinellidae, Cecidomyidae, Hesperidae, Tabanidae and Tephritidae. Group II was slightly tolerant to disturbance, and includes Membracidae, Noctuidae, Ichneumonidae and Apidae. Group III was adapted to the partly-disturbed site and includes Braconidae and Melandryidae. Group IV comprise of dominant families found in all sites, but mostly in the disturbed area's canopy layer, and includes Formicidae, Mycetophilidae and Curculionidae. Group V was adapted to the less-disturbed site and includes mostly scavenging beetle families, such as Scolytidae, Nitidulidae, Staphylinidae, and Carabidae, and flies, such as Phoridae, and several phytophagous beetles, such as Chrysomelidae.

\section{DISCUSSION}

Our study indicates that forest disturbances significantly affected the abundance and family richness of flying insects. Overall, abundances and family richnesses were significantly different among sites. It is not surprising that less-disturbed sites support more flying insects than the most disturbed site. Unlike the disturbed site where florae were less variable, a less-disturbed site was composed of various native woody plants such as Alstonia scolaris and Garcinia dulcis (Table 1). The highly diverse plant species and architecture of the forest would be expected to support a greater abundance and 
richness of canopy insects (Chey et al., 1998).

Among the insect groups, Coleoptera was strongly sensitive to disturbance. The abundance and family richness declined along with the disturbance gradient. In addition, significant interaction effects were observed between site and season, indicating that the combined effects of disturbance and seasonal variations influence both the abundance and family richness in Coleoptera. Herbivorous insects, such as some phytophagous beetles and Orthoptera, were most strongly affected by the disturbances. Similarly, Lawton et al. (1998) found the species richness of flying beetles to be lower in disturbed sites than in an old-growth secondary forest. Different factors may be responsible for this low abundance of herbivores in a disturbed site. First, the mechanism is assumed to be related to the vegetation cover, wherein herbivores are most abundant in sites with high herbaceous cover and low canopy cover (Shure \& Philips, 1991; Bellocq \& Smith, 2003). Second, herbivorous beetles are thought to be highly specialized to their host-plants (Mawdsley \& Stork, 1997). In this study, the percentage of canopy cover and height of woody trees were very similar, but understorey cover and shrub/grass species were clearly different (Table 1). This indicates that change in the understorey shrub species composition and percentage of cover due to the disturbance, influenced the abundance of some herbivorous insects and the existence of some beetle families.

Other beetles, such as Scolytidae and Nitidulidae, were also affected by disturbances. The effect of disturbances is usually greater on the ultra-specialist arthropods (Chey et al., 1998). Therefore, specialist insects, such as some scavenging beetles with narrow spectrum of food, are vulnerable to disturbance because of the low availability of their resources. A woodborer beetle family, Scolytidae, which is commonly dependent on the availability of wood, was very scarce in the highly-disturbed site. This confirms the hypotheses that forest disturbances lead to habitat destruction and reduction of food resources. In addition, differences in beetle abundance between the wet and dry seasons may be explained by seasonal variations in food availability (Wagner, 2003).

The family richness in Hymenoptera also decreased with increasing site disturbance, but the abundance was less variable among the sites. It seems that the abundance of Formicidae in the highly-disturbed was responsible for this. Similarly, Watt et al. (1997) found that the number of individual leaf-litter Formicidae was greater in sites where there had been partial mechanical clearance (removal of most understorey and $50 \%$ of the canopy). Another study also indicated that many tropical ants are considered to be generalists (Floren \& Linsenmair, 1997). The existence of Homoptera in

Table 3. Mean flying insect abundances $( \pm \mathrm{SE}, n=8)$ by disturbance level and season in canopy of secondary forest in Trawas along disturbance gradient, East Java

\begin{tabular}{|c|c|c|c|c|c|c|}
\hline \multirow[t]{2}{*}{ Group } & \multicolumn{2}{|c|}{$\begin{array}{l}\text { Less-disturbed site } \\
\text { (LD) }\end{array}$} & \multicolumn{2}{|c|}{$\begin{array}{l}\text { Partly-disturbed site } \\
\text { (PD) }\end{array}$} & \multicolumn{2}{|c|}{$\begin{array}{l}\text { Highly-disturbed site } \\
\text { (HD) }\end{array}$} \\
\hline & Wet & Dry & Wet & Dry & Wet & Dry \\
\hline Coleoptera & $23 \pm 1.7$ & $21.4 \pm 1.2$ & $18.7 \pm 1.3$ & $12.9 \pm 0.8$ & $13.2 \pm 1.0$ & $7 \pm 0.9$ \\
\hline Curculionidae & $2.4 \pm 0.4$ & $1.8 \pm 0.2$ & $1.9 \pm 0.5$ & $1 \pm 0.2$ & $1.6 \pm 0.5$ & $0.8 \pm 0.2$ \\
\hline Chrysomelidae & $2.3 \pm 0.4$ & $1.4 \pm 0.4$ & $1.4 \pm 0.5$ & $0.8 \pm 0.2$ & $0.6 \pm 0.3$ & $0.2 \pm 0.1$ \\
\hline Scolytidae & $2 \pm 0.2$ & $1.6 \pm 0.4$ & $1.9 \pm 0.5$ & $0.9 \pm 0.2$ & $1.6 \pm 0.4$ & $0.2 \pm 0.1$ \\
\hline Adalia spp. & 0 & 0 & 0.1 & 0.1 & $1.1 \pm 0.2$ & $1 \pm 0.2$ \\
\hline Diptera & $20.4 \pm 1.4$ & $15.2 \pm 1.2$ & $15 \pm 2.4$ & $10.7 \pm 1.7$ & $15.8 \pm 1.6$ & $11.8 \pm 1.2$ \\
\hline Mycetophilidae & $5.8 \pm 0.6$ & $3.8 \pm 0.6$ & $2.5 \pm 0.7$ & $2.5 \pm 0.7$ & $3.2 \pm 0.9$ & $3.4 \pm 0.9$ \\
\hline Ceratopogonidae & $2.2 \pm 0.3$ & $1.4 \pm 0.3$ & $1.3 \pm 0.4$ & $0.7 \pm 0.3$ & $1.9 \pm 0.3$ & $1.9 \pm 0.2$ \\
\hline Hymenoptera & $12.9 \pm 0.9$ & $8.5 \pm 0.7$ & $13.5 \pm 1.7$ & $7.8 \pm 1.1$ & $11.2 \pm 1.0$ & $6.7 \pm 0.6$ \\
\hline Formicidae & $4.3 \pm 0.6$ & $1.6 \pm 0.5$ & $4.3 \pm 0.6$ & $1.9 \pm 0.3$ & $7.6 \pm 1.6$ & $3.5 \pm 0.7$ \\
\hline Lepidoptera & $2.9 \pm 0.6$ & $5.1 \pm 0.5$ & $3.7 \pm 1.1$ & $2.8 \pm 0.8$ & $5.2 \pm 0.6$ & $3.7 \pm 0.5$ \\
\hline Noctuidae & $1 \pm 0.2$ & $1 \pm 0.2$ & $0.9 \pm 0.3$ & $0.6 \pm 0.2$ & $1.5 \pm 0.2$ & $1.5 \pm 0.2$ \\
\hline Erionota thrax & 0 & 0 & 0 & 0 & $1.4 \pm 0.2$ & $1 \pm 0.2$ \\
\hline Homoptera & $3.3 \pm 0.2$ & $2 \pm 0.3$ & $2.2 \pm 0.6$ & $0.9 \pm 0.3$ & $3.4 \pm 0.9$ & $2 \pm 0.2$ \\
\hline Hemiptera & 0 & 0 & $2 \pm 0.6$ & $1.2 \pm 0.6$ & 0 & 0 \\
\hline Isoptera & $1.9 \pm 0.2$ & $1 \pm 0.2$ & $3.6 \pm 1.0$ & $1.6 \pm 0.4$ & $2.4 \pm 0.6$ & $0.8 \pm 0.3$ \\
\hline Total & $68.6 \pm 3.5$ & $55.4 \pm 2.5$ & $58.5 \pm 5.5$ & $39.3 \pm 3.4$ & $53.9 \pm 2.8$ & $33.5 \pm 2.0$ \\
\hline
\end{tabular}


the highly-disturbed site (Table 3) may also support the high abundance of Formicidae in this site. The coexistences of Formicidae and Homoptera have been observed in a number of studies (Schowalter, 1995; Floren \& Linsenmair, 2001).

Our study did not indicate any major effect of stratification. The abundance and family richness did not show any significant differences between understorey and canopy layer. Results of studies on the vertical distribution of canopy insects and abundance in tropical forests are varied. It has been reported that canopy insects are much richer than understorey insects (Erwin, 1982; Basset et al., 1992). However, it has also been seen that canopy insects can be as equally rich and largely similar to understorey insects (Winchester, 1997; Hammond et al., 1997; Schowalter \& Ganio, 1998). These results may indicate that canopy generalist insects are more dominant than layer specialist insects. Interestingly, results of this study showed that similarities between understorey and canopy layer ranged from $74 \%$ to $84 \%$, suggesting that some degree of dissimilarity may exist in the composition of families, rather than in the abundance and richness.

The composition of flying insect assemblages in the highly-disturbed site differed distinctly from the lessdisturbed site and partly-disturbed site. In general, family composition changes with increasing disturbance in lowland tropical rainforests (Chey et al., 1998; Floren \& Linsenmair, 2001). Habitat destruction in a disturbed site leads to the establishment of a new insect community. A study shows that many tramp and generalist species invade modified habitat and replace the role of native and specialist species (Chudzicka \& Skibinska, 1998).

This study demonstrated that site was a determinant factor in generating the variation in abundance of canopy insect families. CCA ordination analyses showed that some families, such as Coccinellidae, Hesperidae, Tephritidae, were grouped in the highly-disturbed site. This may be due to the high abundance of several agricultural species belonging to these families, such as Adalia spp. (Coccinellidae), Erionota thrax (Hesperidae) and Bactrocera spp. (Tephritidae), in this site. Another study shows that some agricultural plant species are hosts, such as Musa paradisiacal acting as host for Erionota thrax (Hasyim et al., 1994). These results suggest that conversion of secondary forest into an agricultural area (plantation) for several agricultural plant species, such as Capsicum sp., Musa paradisiaca and Zea mays, creates a new habitat for the establishment of agricultural insect species.

ACKNOWLEDGEMENTS We are indebted to Anisa Zairina, M. Arif, M. Suroso, Eko, Walesa, Bahrul, Agus and Maman for their logistical and practical help during sampling. We wish to express our sincerest thanks to PPLH/ Environmental Education Center, Seloliman Trawas and the Laboratory of Ecology and Animal Diversity, Department of Biology, Brawijaya University for permitting and supporting our study. We also thank Saiful Arif Abdullah and Jhonamie Mabuhay for their useful advice and comments on the manuscript.

\section{REFERENCES}

Basset, Y., Aberlenc, H., \& Delvare, G. 1992. Abundance and stratification of foliage arthropods in a lowland rain forest of Cameroon. Ecological Entomology 17: 310-318.

Basset, Y., Novotny, V., Miller, S.E., \& Kitching, R. L. 2003. Methodological advances and limitations in canopy entomology. In Basset, Y., Novotny, V., Miller, S. E., \& Kitching, R. L. (eds.) Arthropods of Tropical Forests, Pp. 7-16. Cambridge University Press, Cambridge.

Bellocq, M. I., \& Smith S. M. 2003. Convergence in arthropod assemblages with various restoration approaches for Canadian deciduous forests. Journal of Insect Conservation 7: 99-109.

Borror, D. J., Triplehorn, C. A. \& Johnson, N. F. 1989. An Introduction to the Study of Insects. Sounders College Publishing, New York.

Chey, V. K., Holloway, J. D., Hambler, C., \& Speight, M. R. 1998. Canopy knockdown of arthropods in exotic plantation and natural forest in Sabah, north-east Borneo, using insecticidal mist-blowing. Bulletin of Entomological Research 88: $15-24$.

Chudzicka, E. \& Skibinska, E. 1998. Diversity of reaction of insects communities as a response to anthropogenic pressure. Memorabilia Zoologica 51: 13-30.

Didham, R. K. 1997. Dipteran three crown assemblages in a diverse southern temperate rainforest. In Stork, N. E., Adis, J. \& Didham, R. K. (eds.), Canopy Arthropods, Pp. 320-343. Chapman and Hall, London.

Erwin, T. L. 1982. Tropical forests: their richness in Coleoptera and other arthropod species. Coleopterists Bulletin 36: 74 
$-75$.

Floren, A. \& Linsenmair, K. E. 1997. Diversity and recolonization dynamics of selected arthropod groups on different tree species in a lowland rainforest in Sabah, Malaysia with special reference to Formicidae. In Stork, N. E., Adis, J. \& Didham, R. K. (eds.), Canopy Arthropods, Pp. 344-381. Chapman and Hall, London.

Floren, A. \& Linsenmair, K. E. 2001. The influence of anthropogenic disturbances on the structure of arboreal arthropod communities. Plant Ecology 153: 153-167.

Floren, A. \& Linsenmair, K. E. 2003. How do beetle assemblages respond to anthropogenic disturbance? In Basset, Y., Novotny, V., Miller, S. E., \& Kitching, R. L. (eds.) Arthropods of Tropical Forests, Pp. 190-197. Cambridge University Press, Cambridge.

Hamer, K. C., Hill, J. K., Lace, L. A. \& Langhan, A. M. 1997. Ecological and biogeographic effects of forest disturbance on tropical butterflies of Sumba, Indonesia. Journal of Biogeography 24: 67-75.

Hammond, P. M., Stork, N. E. \& Brendell, M. J. D. 1997. Tree-crown beetles in context: a comparison of canopy and other ecotone assemblages in a lowland tropical forest in Sulawesi. In Stork, N. E., Adis, J. \& Didham, R. K. (eds.), Canopy Arthropods, Pp. 184-223. Chapman and Hall, London.

Holloway, J. D. 1998. The impact of traditional and modern cultivation practices, including forestry, on Lepidoptera diversity in Malaysia and Indonesia. In Newbery, D. M., Prins, H. H. T. \& Brown, N. (eds.), Dynamic of Tropical Communities, Pp. 567-597. Blackwell Science, Oxford.

Kalshoven, L. G. E. 1981. Pests of crops in Indonesia. Van der Laan, P. A. (trans. and ed.) PT Ichtiar Baru-Van Hoeve, Jakarta.

Lawton, J. H., Bingnell, D. E., Bolton, B., Bloemers, G. F., et al. 1998. Biodiversity inventories, indicator taxa and effects of habitat modification in tropical forest. Nature 391: 72-76.

Mawdsley, N. A. and Stork, N. E. (1997) Host-specificity and the effective specialization of tropical canopy beetles. Canopy Arthropods (eds. N. E. Stork, J. Adis and R. K. Didham), Pp. 104-130. Chapman and Hall, London.

Natuhara, Y., Imai, C. \& Takahashi, M. 1999. Pattern of land mosaics affecting butterfly assemblage at Mt Ikoma, Osaka, Japan. Ecological Research 14: 105-118.

Roberts, H. R. 1973. Arboreal Orthoptera in the rain forests of Costa Rica collected with insecticide: a report on the grasshopper (Acrididae), including new species. Proceedings of the Academy of Natural Sciences of Philadelphia 125: 46-66.

Schowalter, T. D. 1995. Canopy arthropod communities in relation to forest age and alternative harvest practices in western Oregon. Forest Ecology \& Management 78: 115-125.

Schowalter, T. D. \& Ganio, L. M. 1998. Vertical and seasonal variation in canopy arthropod communities in an old-growth conifer forest in southwestern Washington, USA. Bulletin of Entomological Research 88: 633-640.

Schowalter, T. D. \& Ganio, L. M. 1999. Invertebrate communities in a tropical rain forest canopy in Puerto Rico following Hurricane Hugo. Ecological Entomology 24: 191-201.

Shure D. J. \& Philips, D. L. 1991. Patch size of forest openings and arthropod populations. Oecologia 86: 325-334.

Sokal, R. R. \& Rohlf, F. J. 1995. Biometry, $3^{\text {rd }}$ ed. Freeman, New York.

Su, J. C. \& Woods, S. A. 2001. Importance of sampling along a vertical gradient to compare the insect fauna in managed forest. Environmental Entomology 30: 400-408.

Wagner, T. 2003. Seasonality of canopy beetles in Uganda. In Basset, Y., Novotny, V., Miller, S. E., \& Kitching, R. L. (eds.) Arthropods of Tropical Forests, Pp.146-158. Cambridge University Press, Cambridge.

Watt, A. D., Stork, N. E., Eggleton P., Srivastava, D., et al. 1997. Impact of forest loss and regeneration on insect abundance and diversity. In Watt, A. D., Stork, N. E and Hunter, M. D. (eds.). Forest and insects, Pp. 273-286. Chapman and Hall, London, UK.

Winchester, N. N. 1997. Canopy arthropods of coastal Sitka spruce trees on Vancouver Island, British Colombia, Canada. Canopy Arthropods (eds. N. E. Stork, J. Adis and R. K. Didham), Pp. 151-168. Chapman and Hall, London.

Received 25 ${ }^{\text {th }}$ Nov. 2004

Accepted $5^{\text {th }}$ Apr. 2005 